\title{
The country rocks of Devonian magmatism in the North Patagonian Massif and Chaitenia
}

\author{
Francisco Hervé ${ }^{1,2}$, Mauricio Calderón ${ }^{1}$, C. Mark Fanning ${ }^{3}$, Robert J. Pankhurst ${ }^{4}$, \\ Carlos W. Rapela ${ }^{5}$, Paulo Quezada ${ }^{6}$
}

\author{
1 Carrera de Geología, Facultad de Ingeniería, Universidad Andres Bello, Sazié 2119, Santiago, Chile. \\ fherve@unab.cl; mauricio.calderon@unab.cl \\ 2 Departamento de Geología, Universidad de Chile, Plaza Ercilla 803, Santiago, Chile. \\ fhervé@cec.uchile.cl \\ 3 Research School of Earth Sciences, The Australian National University, Canberra, ACT 0200, Australia. \\ mark.fanning@anu.edu.au \\ 4 Visiting Research Associate, British Geological Survey, Keyworth, Nottingham NG12 5GG, United Kingdom. \\ rjpankhurst@gmail.com \\ 5 Centro de Investigaciones Geológicas, Universidad Nacional de la Plata, Diagonal 113, No 275, 1900 La Plata, Argentina. \\ crapela@cig.museo.unlp.edu.ar \\ 6 Seremi de Minería Región de Aysén, Ministerio de Minería, Avda. Baquedano, No 336, Coyhaique, Chile. \\ p.quezada.pozo@gmail.com
}

\begin{abstract}
Previous work has shown that Devonian magmatism in the southern Andes occurred in two contemporaneous belts: one emplaced in the continental crust of the North Patagonian Massif and the other in an oceanic island arc terrane to the west, Chaitenia, which was later accreted to Patagonia. The country rocks of the plutonic rocks consist of metasedimentary complexes which crop out sporadically in the Andes on both sides of the Argentina-Chile border, and additionally of pillow metabasalts for Chaitenia. Detrital zircon SHRIMP U-Pb age determinations in 13 samples of these rocks indicate maximum possible depositional ages from $c a .370$ to $900 \mathrm{Ma}$, and the case is argued for mostly Devonian sedimentation as for the fossiliferous Buill slates. Ordovician, Cambrian-late Neoproterozoic and "Grenvilleage" provenance is seen throughout, except for the most westerly outcrops where Devonian detrital zircons predominate. Besides a difference in the Precambrian zircon grains, $76 \%$ versus $25 \%$ respectively, there is no systematic variation in provenance from the Patagonian foreland to Chaitenia, so that the island arc terrane must have been proximal to the continent: its deeper crust is not exposed but several outcrops of ultramafic rocks are known. Zircons with devonian metamorphic rims in rocks from the North Patagonian Massif have no counterpart in the low metamorphic grade Chilean rocks. These Paleozoic metasedimentary rocks were also intruded by Pennsylvanian and Jurassic granitoids.
\end{abstract}

Keywords: Devonian, Metamorphic complexes, U-Pb zircon ages, North Patagonian Massif, Chaitenia.

RESUMEN. Las rocas huésped del magmatismo Devónico en el Macizo Norpatagónico y Chaitenia. Trabajos anteriores han demostrado que el magmatismo devónico en los Andes meridionales se produjo en dos cinturones contemporáneos: uno emplazado en la corteza continental del Macizo Norpatagónico y el otro, hacia el oeste, en un arco de islas oceánico, Chaitenia, que más tarde se acrecionó a Gondwana. Las rocas hospedantes de las rocas plutónicas consisten en complejos metasedimentarios que aparecen esporádicamente en los Andes a ambos lados de la frontera entre Argentina y Chile, y adicionalmente de metabasaltos de almohadilla en Chaitenia. Las determinaciones de la edad de U-Pb de circones detríticos en 13 muestras de estas rocas metasedimentarias indican edades deposicionales máximas posibles de $c a .370$ a $900 \mathrm{Ma}$, y se argumenta que la sedimentación es principalmente del Devónico similar a las pizarras fosilíferas de Buill. Procedencia del Ordovícico, del Cámbrico-tardío a Neoproterozoico y "Grenville” se ve en todas 
las rocas, a excepción de los afloramientos más occidentales donde predominan los zircones detríticos del Devónico. Además de una diferencia en los granos de zircón precámbricos, $76 \%$ versus $25 \%$ respectivamente, no hay variación sistemática en la procedencia del antepaís patagónico a Chaitenia, por lo que el arco de islas debe haber sido proximal al continente: su corteza más profunda no está expuesta pero se conocen varios afloramientos de rocas ultramáficas. Los bordes metamórficos desarrollados durante el Devónico en circones de las rocas del Macizo Norpatagónico no tienen su equivalente en los circones de las rocas metamórficas de bajo grado del sector chileno. Estas rocas metasedimentarias paleozoicas también fueron intruidas por granitoides del Pennsylvaniano y Jurásico.

Palabras clave: Devónico, Complejos metamórficos, Edades U-Pb en circones, Macizo Norpatagónico, Chaitenia.

\section{Introduction}

The Paleozoic evolution of the western margin of Gondwana in its South American segment is thought to have involved successive collision of microcontinental terranes and associated orogenies that developed along the margin (Fig. 1). However, the lithological constitution and extent of these terranes, in particular Chilenia, has been difficult to assess due to poor exposure and, locally, the lack of precise dating of the rocks.

Álvarez et al. (2009, 2011, 2013a,b) studied metamorphic complexes in areas close to Gneisses de la Pampa outcrops, in the Huasco Valley of northern Chile, which were initially considered to represent the crust of Chilenia (Ramos et al., 1984), but were later shown to be a metamorphosed Carboniferous pluton (Álvarez et al., 2009; Hervé et al., 2014). Álvarez et al. (2011) found a population of 580 to $530 \mathrm{Ma}$ detrital zircon ages which they consider to have been derived from the erosion of a magmatic/metamorphic source that possibly forms a significant component of the Chilenia microcontinent. Zircon U-Pb data obtained in the Quebrada Seca Schists, a metamorphic unit which crops out near the Pampa gneisses, yielded an age of $486 \pm 6.5 \mathrm{Ma}$ (Álvarez et al., 2013a) and allowed the conclusion that the plutonic protolith of this unit was emplaced in the Chilenia terrane close to the time of the Cambrian-Ordovician boundary, i.e., before the Devonian collision. According to the same authors, the Quebrada Seca Schists are the only known exposed rocks of the Chilenia basement in Chile. However, the assumption that the Quebrada Seca schists have an igneous protolith is not documented, and the analytical data were not presented.

In the present-day North Patagonian Andes, recent SHRIMP U-Pb dating of the crystallization age of zircon from intrusive igneous bodies, together with their O and Lu-Hf isotopic characteristics (Hervé et al., 2016), suggested that Devonian igneous rocks constituted two magmatic belts: an eastern one emplaced in the continental crust of Patagonia and the other developed in an oceanic island arc to the west that was later accreted to Gondwana. The oceanic island arc terrane has been referred to as Chaitenia (Hervé et al., 2016) and is thought to have extended southwards from the Huincul lineament, the southern limit of Chilenia (Ramos et al., 1984). Chernicoff et al. (2013) have proposed that a Devonian magmatic arc was developed over the western edge of a "Southern Patagonia terrane", during east-directed subduction previous to collision with Patagonia, but they considered that the arc was built over an old continental fragment.

As a step towards characterising the nature of the crust into which the two magmatic belts were emplaced, we present SHRIMP U-Pb zircon ages on detrital zircons from thirteen samples of metamorphic rocks from the surrounding areas of known Devonian intrusive bodies, as well as four further crystallization ages of plutons which intrude them. Localities sampled in Chile are indicated in the 1:1.000.000 Geological Map of Chile (SERNAGEOMIN, 2003) as Devonian-Carboniferous or Paleozoic-Triassic based on lithological correlation with mapped and dated units. Those in Argentina belong to the widespread Colohuincul Complex and Cushamen Formation.

\section{Geological setting}

Devonian plutonic rocks are known from various localities in the studied region (Fig. 2), among which some now have well-established U-Pb ages close to $400 \mathrm{Ma}$ (Pankhurst et al., 2006; Godoy et al., 2008; Hervé et al., 2013); these include tonalites and granites around San Martín de los Andes and porphyritic granite at Colán Conhue, southeast of Esquel. Further Devonian intrusive rocks are now known along the western slope of the Andes at Pichicolo, Chaitén and Yelcho lake (Hervé et al., 2016). 


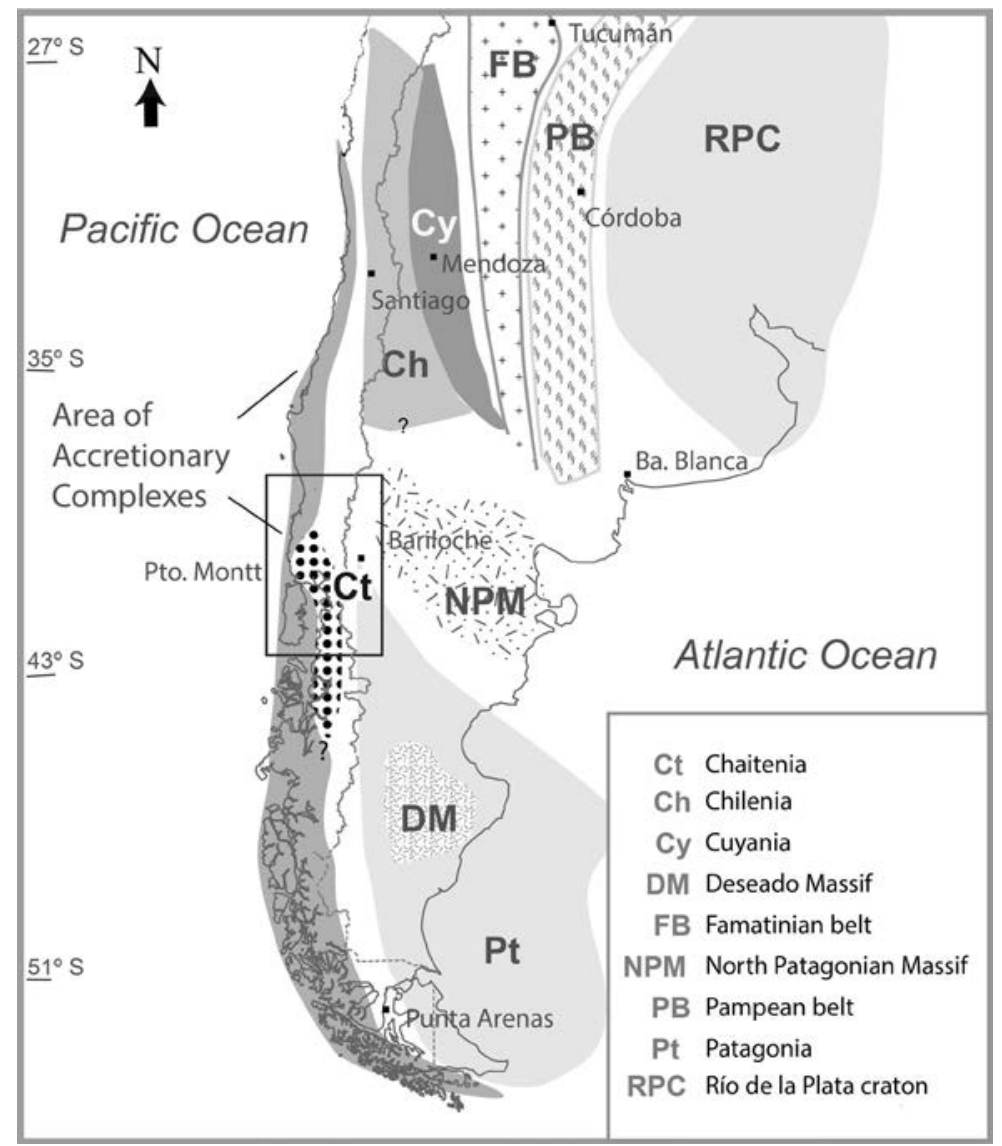

FIG. 1. General location map of the studied area in the north Patagonian Andes and Massif.

The Pre-Jurassic basement of Patagonia contains sedimentary or metasedimentary rocks that generally lack preserved fossils and have long been considered to be Paleozoic or Proterozoic. In the studied area on the Chilean side of the Andes such rocks are comparable to those in the extensive Eastern Andes Metamorphic complex (Hervé, 1988; Hervé et al., 2007) where previous U-Pb dating of detrital zircon has suggested Devonian to Late Triassic depositional ages (Hervé et al., 2003). Low-grade slates at Buill (Fig. 2) are uniquely associated with trilobite fossils (Levi et al., 1966; Fortey et al., 1992), albeit so far only found in boulders lithologically similar to rocks cropping nearby. They are taken as marking a reliable Devonian age for deposition of the slate protolith. The relationship to turbidite successions and pillow basalts and associated ultramafic rocks in the vicinity (Crignola, 1999; Hervé et al., 2017) has not been established clearly, as outcrops in this area are sparse and with difficult access due to dense forests. Metamorphic rocks in the Coastal Range are assigned to a paleo-accretionary complex which is represented as of Paleozoic-Triassic age on the 1:1.000.000 Geological Map of Chile. The eastward extension of the accretionary complex is not well established.

On the Argentine side of the Andes, similar low-grade metasedimentary rocks are represented by the Colohuincul Complex in the cordilleran zone around Bariloche (Fig. 2) (Dalla Salda et al., 1991) and the Cushamen Formation farther east (Varela et al., 2005). A Devonian age for the latter seems reasonable on the basis of $\mathrm{Rb}-\mathrm{Sr}$ whole-rock data (Ostera et al., 2001) and U-Pb zircon data for a sample thought to be part of the formation from south of El Maitén that shows Silurian provenance and significant Devonian metamorphism (Pankhurst et al., 2006). 


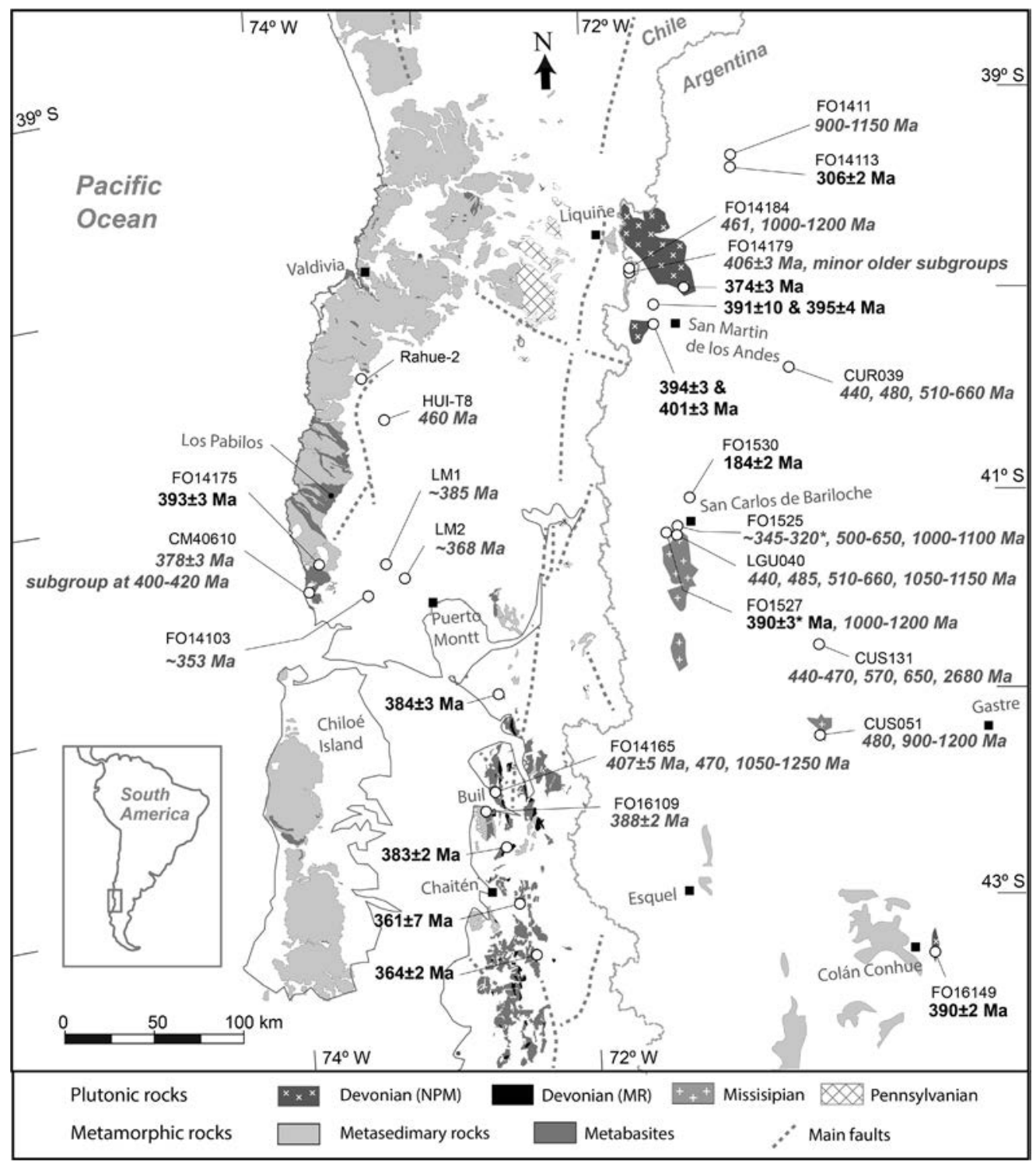

FIG. 2. SHRIMP zircon ages in the studied area. Grey numbers indicate main age peaks of detrital zircons in metasedimentary rocks; * indicates metamorphic ages; numbers in bold type are igneous rock crystallization age. Data from this paper and Hervé et al. (2016).

In the Colohuincul Formation, García-Sansegundo et al. (2009) presented evidence for early highpressure deformation and metamorphism followed by intermediate-low grade conditions during decompression. Electron microprobe Th-U-Pb dating of monazite from high-pressure migmatites (Cruz Martínez et al., 2012) yielded ages of $392 \pm 4$ and $350 \pm 6 \mathrm{Ma}$, which were assigned to these events; they ascribed the metamorphism to Devonian collision of Chilenia with Patagonia, implying southward extension of the Chilenia terrane to the present $41^{\circ} \mathrm{S}$ latitude. Other previous maximum possible depositional ages in the Colohuincul Complex are the ca. $1000 \mathrm{Ma}$ (Ramos et al., 2010) at Cuesta de Rahue, $420 \mathrm{Ma}$ in a schist enclave in the $401 \mathrm{Ma}$ San Martín tonalite, and ca. $380 \mathrm{Ma}$ in a paragneiss in the main range near Liquiñe (Hervé et al., 2016). 


\section{Methodology}

Samples were collected from localities displaying the typical outcrop characteristics of the different units, as detailed below. Petrographical observations in thin sections and X-ray diffraction (XRD) studies were carried out at the Laboratory for the Analysis of Solids (LAS) at Universidad András Bello, Santiago. For samples numbered with the prefix FO, zircon was separated by standard methods of crushing, grinding, Wilfley table, magnetic and heavy liquids at Universidad de Chile, Santiago. Zircon separation for earlier samples from Argentina was carried out in a similar way at British Geological Survey, UK.

Isotopic analyses were undertaken at the Research School of Earth Sciences, The Australian National University, Canberra. Zircon grains were mounted in epoxy and polished to about half-way through. Cathodo-luminescence (CL) images were obtained for all grains to select appropriate areas for analysis. $\mathrm{U}-\mathrm{Th}-\mathrm{Pb}$ analyses were carried out using sensitive high-resolution ion microprobes (SHRIMP II and SHRIMP RG) following procedures similar to those described by Williams (1998 and references therein). From each sample, 15 to 20 grains were analysed when an igneous crystallization age was required, and 60 or more grains if possible when identification of sedimentary provenance was the objective. Crystallization ages, where calculated, are reported here with $95 \%$ confidence limits. The International Chronostratigraphic Chart time-scale of Cohen et al. (2013) is used throughout.

\section{Results}

The results obtained are summarized in table 1 and discussed below. U-Pb isotope plots and detrital zircon age distributions are shown in figures 3-5 and data for the igneous samples in figure 6 .

\subsection{Metasedimentary rocks}

FO14111 is a massive white mica schist, collected from the highest outcrop at Cuesta de Rahue, North Patagonian Massif, in Argentina. It has planar Sp N75W/44N and planar cross-cutting quartz-chlorite veins up to $50 \mathrm{~cm}$ wide. $\mathrm{U}-\mathrm{Pb}$ ages of zircons (Fig. 3) indicate a broad spectrum in the relative probability diagram, predominantly in the range $930-1380 \mathrm{Ma}$ with a main peak at $c a .1050 \mathrm{Ma}$, but also with eight
${ }^{206} \mathrm{~Pb} /{ }^{238} \mathrm{U}$ ages in the range $485-845 \mathrm{Ma}$ (three of these close to $500 \mathrm{Ma}$ ). Due to their scattered nature it is not possible to confidently assign an age to the youngest provenance, but the depositional age is certainly younger than $900 \mathrm{Ma}$, possibly younger than $480 \mathrm{Ma}$. Schist from a nearby locality analysed by Ramos et al. (2010) gave a ca. 1,000 Ma age for the youngest detrital zircons; according to these authors the schists here belong to the Colohuincul Complex and were thrust towards the west.

FO14179 from Río Lipinza is a hornfels, probably indicating a sandstone protolith, which was sampled as an enclave in a dioritic intrusive rock emplaced in mica schist together with a suite of aphanitic to microphaneritic dykes. The obtained zircon age distribution (Fig. 3) shows a youngest concentration of $c a .400 \mathrm{Ma} ; 19$ of these give a weighted mean of $406 \pm 3 \mathrm{Ma}$ which is taken as pertaining to an Early Devonian igneous intrusion in the provenance area. The detrital pattern also shows minor Ordovician, Neoproterozoic, Mesoproterozoic and Archaean peaks. In the Geological Map of Chile (SERNAGEOMIN, 2003) the location of this sample, as well as the one that follows (FO14184), is labelled as Liquiñe Metamorphic Complex, of Paleozoic to Triassic age.

FO14184 is a schist boulder from estero El Loco, lithologically similar to coarse-grained schists that crop out in this small stream with a limited catchment area. It is a quartzose banded metasandstone containing biotite, white mica and garnet, with a sub-vertical NW main foliation. The local schists contain andalusite and cordierite porphyroblasts, indicating medium-grade low $\mathrm{P} / \mathrm{T}$ metamorphism, probably related to igneous intrusions known to occur in the area (see below). The detrital zircon ages (Fig. 3) indicate a dominant "Grenville" peak at $1090 \mathrm{Ma}$, tailing off to $c a$. $1450 \mathrm{Ma}$. There a few apparent late Neoproterozoic ages but the youngest three seem to define Late Ordovician provenance, limiting deposition to post-460 Ma. Regional proximity and age pattern similarity with FO14179 suggest a similar depositional age for both samples.

CUR039 is a schist from Collon Curá, southwestern Río Negro Province. The outcrop, located at route RN234, $8 \mathrm{~km}$ north of junction with RN237, is injected by leucocratic veins and mafic dykes, but the sample is from a vein-free area. The major inheritance ranges in age from 400 to $660 \mathrm{Ma}$, with peaks at 440-470, 510 and 580-610 Ma (Fig. 3) Four younger grains (320-365 Ma) have high common $\mathrm{Pb}$ and may have been affected by the later intrusions. 


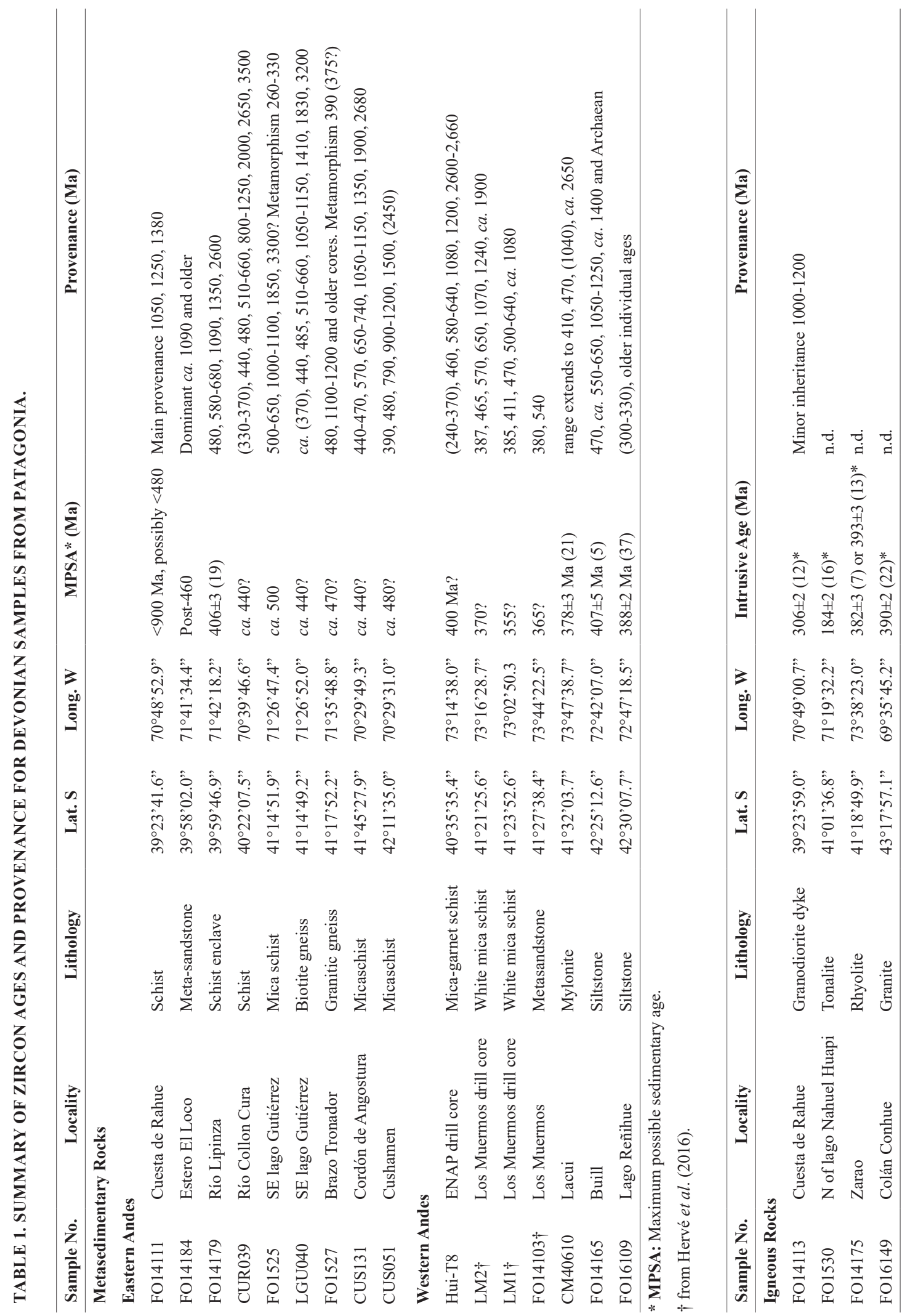



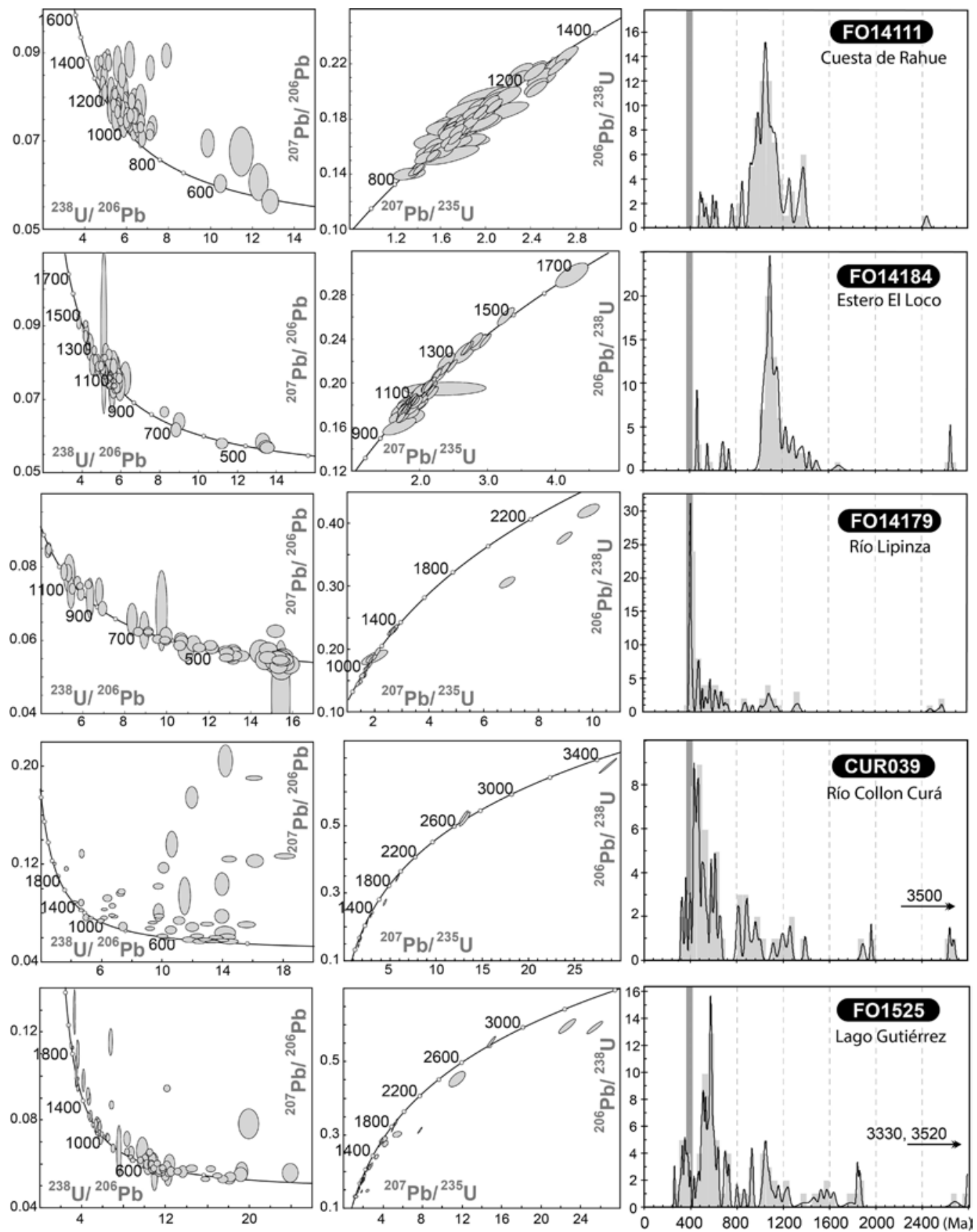

FIG. 3. Tera-Wasserburg (data uncorrected for common $\mathrm{Pb}$ ), Wetherill $\left({ }^{204} \mathrm{~Pb}\right.$-corrected) and preferred age versus frequency/relative probability diagrams for metasedimentary rock sample zircon from the eastern (continental) Devonian belt (continued in figure 4)

The depositional age is post-Ordovician, possibly Devonian. There is minor older provenance at 800 $1400 \mathrm{Ma}$ as well as traces at $c a .1900$ and $2650 \mathrm{Ma}$ and a single concordant grain at $3500 \mathrm{Ma}$.
FO1525 is a mica schist from the southeastern end of lago Gutiérrez. The U-Pb zircon age distribution (Fig. 3) shows prominent but dispersed clusters between 500 and $650 \mathrm{Ma}$, rather minor 

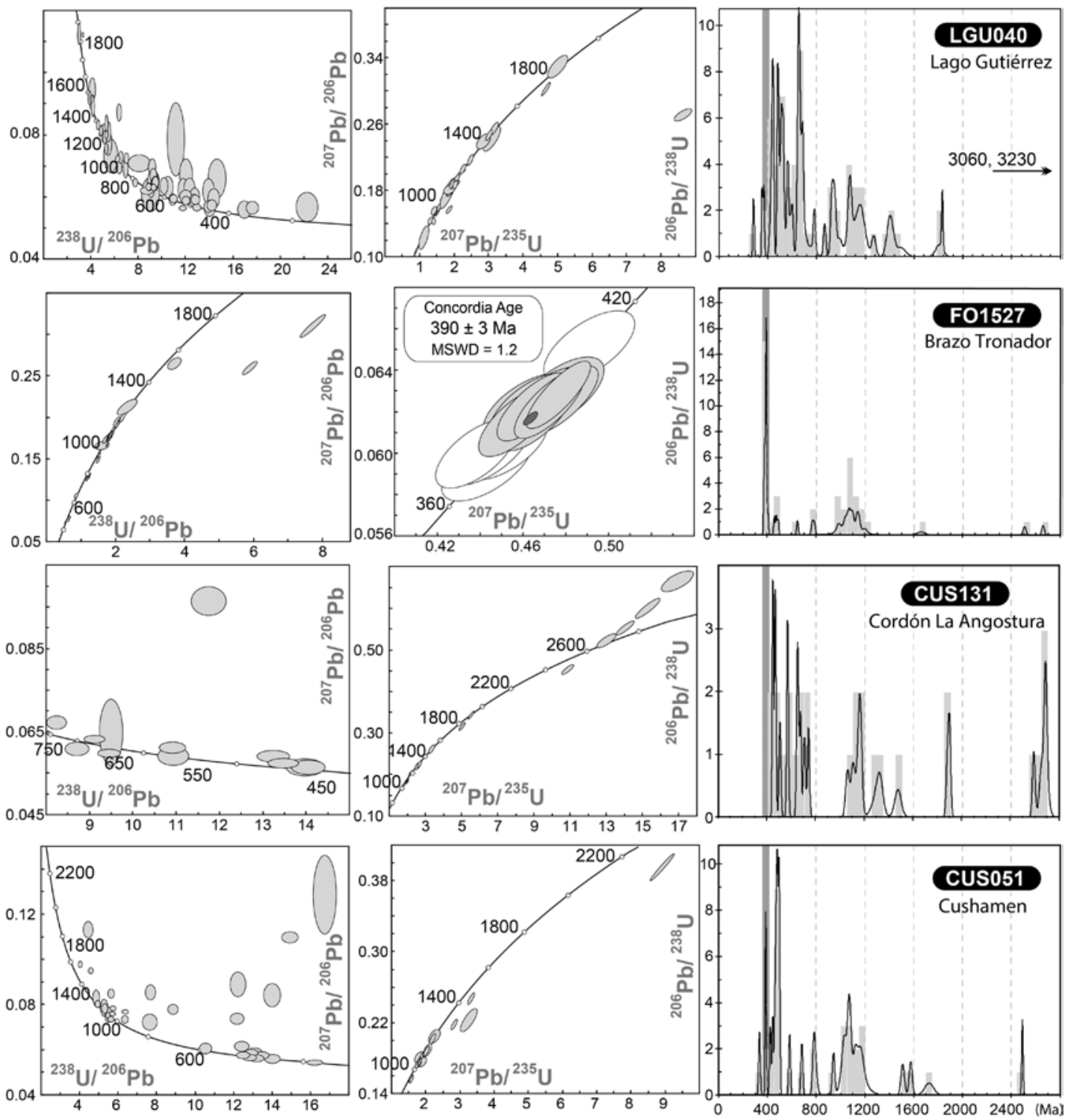

FIG. 4. Continuation of figure 3. The age for FO1527 is a Concordia Age (sensu Ludwig, 2003) for metamorphic zircon rims, ignoring the data plotted as white ellipses; uncertainty level is $2 \sigma$.

“Grenville-age" peaks (1050 Ma) and ca. $1850 \mathrm{Ma}$, as well as some Archaean ages back to $c a .3500 \mathrm{Ma}$. At the younger end of the spectrum scattered Late Paleozoic ages include four clear metamorphic rims with Permo-Carboniferous ages of 260-330 Ma. This sample shows little evidence of either Ordovician or Devonian provenance, nor of Early Devonian metamorphism. This and the two following samples form part of the Colohuincul Complex (Cruz Martínez et al., 2012).
LGU040 is a sample of biotite gneiss taken from very close to the locality of FO1525. The zircon age spectrum (Fig. 4) shows a single grain at $284 \mathrm{Ma}$ and two at $c a .360 \mathrm{Ma}$, the reality of which is confused by rather high common $\mathrm{Pb}$, but a peak at $400 \mathrm{Ma}$ followed by the main one at $485 \mathrm{Ma}$. The older part of the distribution spectrum is very similar to that of FO1525, with significant peaks at 520, 570 and $660 \mathrm{Ma}$ and the same spread of Mesoproterozoic, Paleoproterozoic and Archaean ages. 

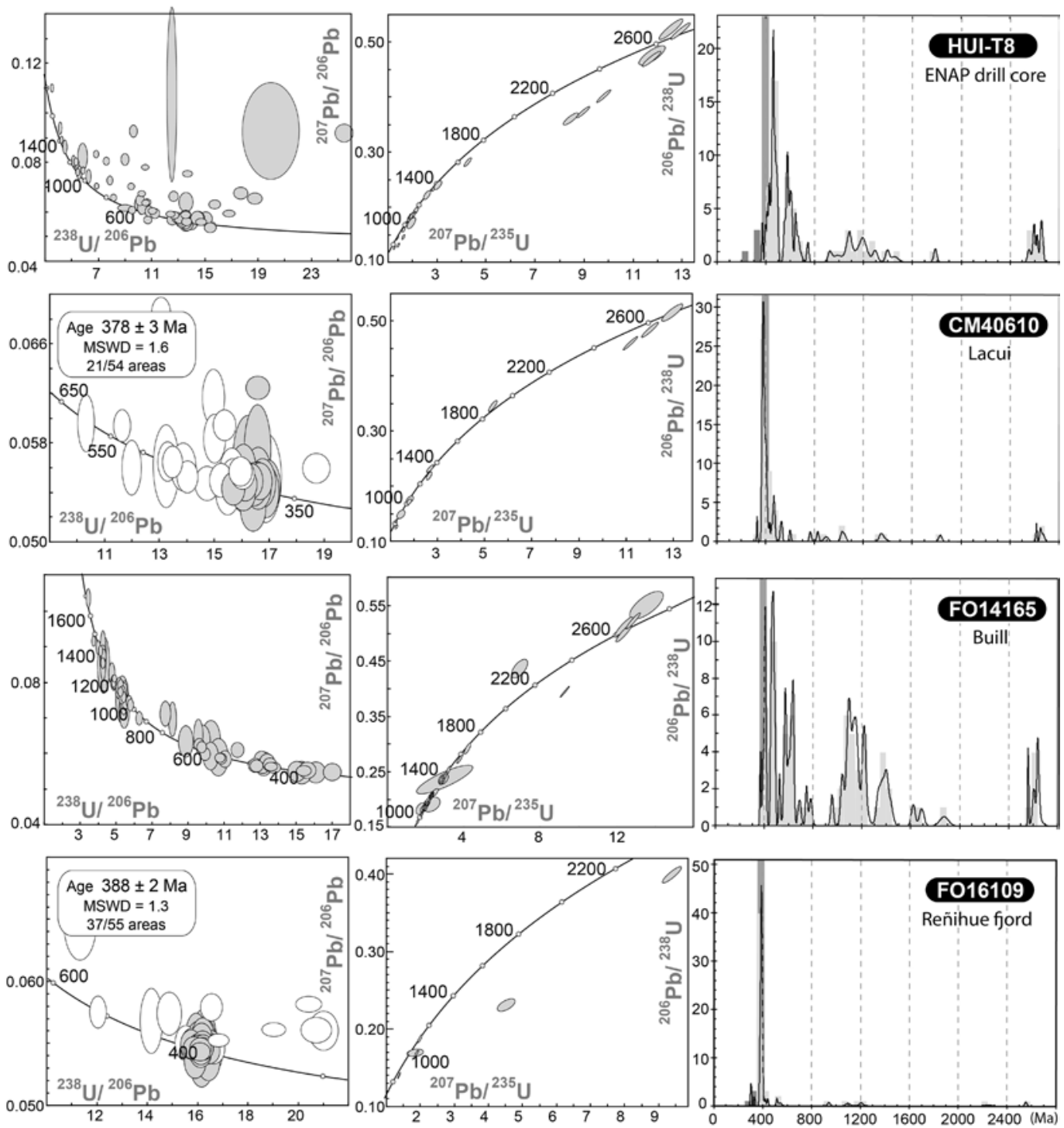

FIG. 5. Tera-Wasserburg (data uncorrected for common $\mathrm{Pb}$ ), Wetherill $\left({ }^{204} \mathrm{~Pb}\right.$-corrected) and preferred age versus frequency/relative probability diagrams for metasedimentary rock sample zircon from the western Devonian belt (island arc). The ages for significant clusters shown for CM40610 and FO16109 are weighted mean ${ }^{206} \mathrm{~Pb} /{ }^{238} \mathrm{U}$ ages after correction for common $\mathrm{Pb}$ using the ${ }^{207} \mathrm{~Pb}$ measurements; uncertainties are $2 \sigma$.

FO1527 is a granitic gneiss from lago Mascardi (Brazo Tronador) shows Devonian ages (370$400 \mathrm{Ma}$ ) for zircon areas with extremely low $\mathrm{Th} / \mathrm{U}$ ratios, which are interpreted as metamorphic rims (Fig. 4). Of these, the four youngest yield a weighted mean age of $376 \pm 5 \mathrm{Ma}$, whereas 11 others yield $390 \pm 3$ Ma. The latter result confirms the Devonian age of the main metamorphism obtained by Cruz Martínez et al. (2012); the former may reflect slight $\mathrm{Pb}$-loss, but is still older than the $350 \pm 6 \mathrm{Ma}$ assigned by Cruz Martínez et al. (2012) to lowgrade post-metamorphic decompression. Our data for zircon cores with normal igneous $\mathrm{Th} / \mathrm{U}$ ratios show a range of Ordovician, "Grenvillian" and older ages similar to the above samples. CL images show some of the $c a .1000 \mathrm{Ma}$ areas to be overgrowths, suggesting a "late-Grenvillian" metamorphism. 

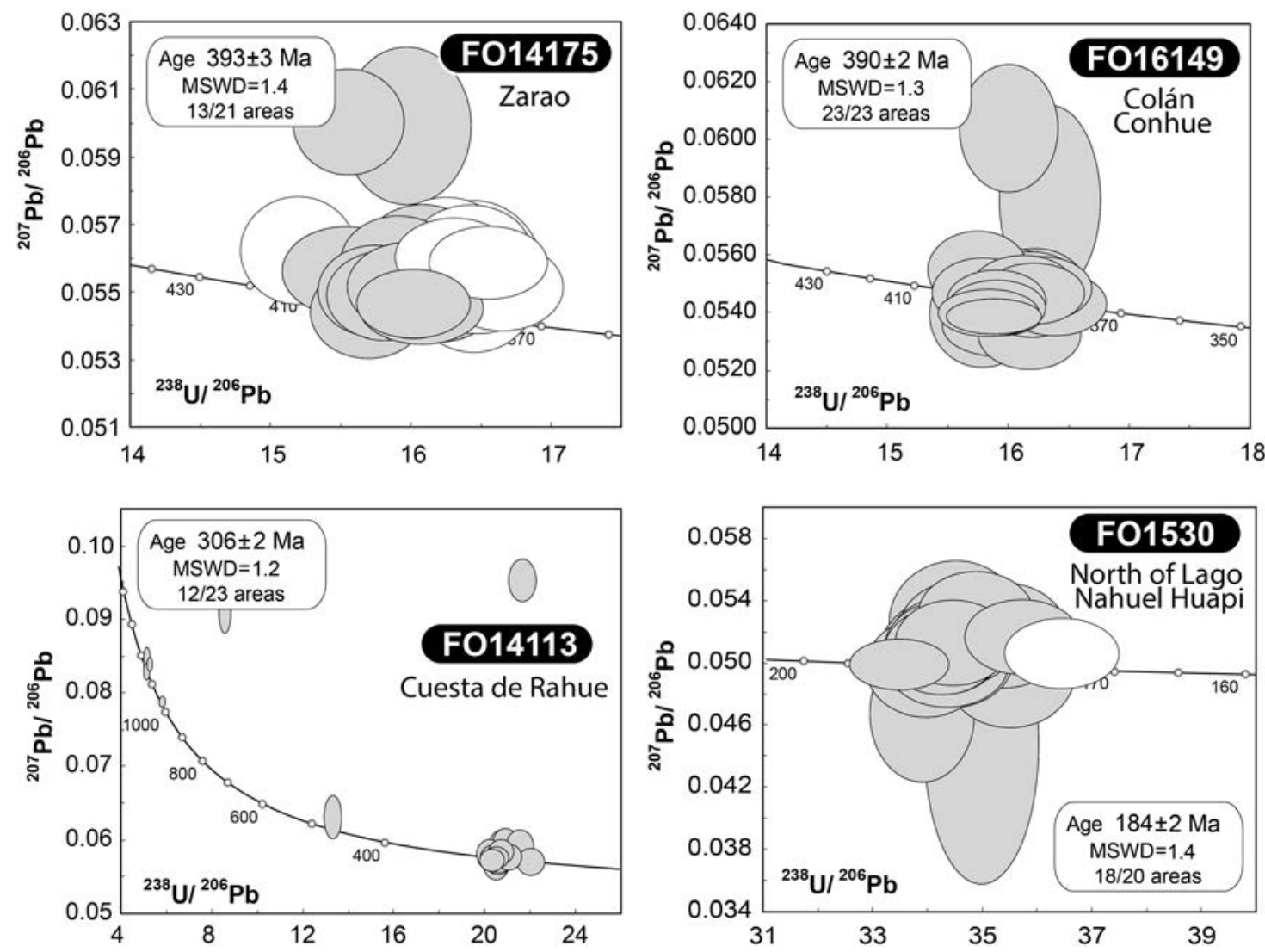

FIG. 6. Tera-Wasserburg diagrams for igneous rock zircons dated in this study. The calculated ages are weighted mean ${ }^{206} \mathrm{~Pb} /{ }^{238} \mathrm{U}$ ages after correction for common $\mathrm{Pb}$ using the ${ }^{207} \mathrm{~Pb}$ measurements, ignoring data plotted as white ellipses; uncertainties are $2 \sigma$.

CUS131 is a Cushamen Formation schist sample from río Chico (Cordón de la Angostura) in Río Negro province, $32 \mathrm{~km}$ east of Ñorquinco. The youngest zircon ages obtained are 440-460 Ma (Fig. 4). Other significant groups are Late Neoproterozoic (570, $650 \mathrm{Ma}$ ), Mesoproterozoic (1000-1200 and 1,400 Ma), ca. $1900 \mathrm{Ma}$ and 2600$2700 \mathrm{Ma}$.

CUS051 is another mica schist sample from the Cushamen Formation, $14 \mathrm{~km}$ east of Cushamen village. The main provenance is Early Ordovician, the main peak in the distribution being at $480 \mathrm{Ma}$ (Fig. 4). Younger ages are mostly associated with high common $\mathrm{Pb}$ but there is one good analysis at $385 \mathrm{Ma}$. There is a significant Mesoproterozoic group at $1000-1200 \mathrm{Ma}$ with a peak at $1070 \mathrm{Ma}$.

FO14165 is a $10 \mathrm{~cm}$ thick low-grade finegrained metasandstone interbedded with dark grey slates near the town of Buill. This unit, as well as that of the following sample, belongs to the Paleozoic-Triassic unit in the Geological Map of Chile (SERNAGEOMIN, 2003). U-Pb data were originally reported by Hervé et al. (2017) but are repeated here as a control for comparison (Fig. 5). The zircon age versus probability diagram shows wide dispersion, with some poorly-defined age peaks corresponding to Devonian, Ordovician, 550-650 Ma, early "Grenville" (1100-1250 Ma), ca. $1400 \mathrm{Ma}$ and even Archaean. This is the only sample with a constrained stratigraphic age independent of the $\mathrm{U}-\mathrm{Pb}$ zircon dating: the depositional age of this unit is well established by its trilobite content, which led Fortey et al. (1992) to consider the fossil fauna as of Malvinokaffric affinities and indicating Lower to early Middle Devonian (Emsian-Eifelian) deposition. Five of the youngest grains give a good weighted mean ${ }^{206} \mathrm{~Pb} / 238 \mathrm{U}$ age of $407 \pm 5 \mathrm{Ma}$, which is consistent with this depositional age. 
FO16109 from the southwest shore of Reñihue fjord is a fine-grained metasandstone (Fig. 7A, B) interbedded with pillow metabasalts (Fig. 7B, C). The three youngest ${ }^{206} \mathrm{~Pb} /{ }^{238} \mathrm{U}$ ages obtained are $c$. $303 \mathrm{Ma}$, and another is $c a$. $330 \mathrm{Ma}$, but almost all the remainder fall in the range $375-400 \mathrm{Ma}$, from which 37 give a weighted mean of $388 \pm 2 \mathrm{Ma}$, with an acceptable MSWD of 1.3 (Fig. 5). The younger ages are all associated with rather high common $\mathrm{Pb}$ contents and may not be reliable. Thus the most robust estimate for a maximum depositional age is Middle Devonian, and the sediment protolith could well be part of the Devonian basement, as well as the enclosing pillow metabasalts.

HUI-T8 is a mica schist from the bottom of ENAP borehole HUILMA-1 west of Osorno. The youngest five zircons dated (Fig. 5) are spaced out in the range 235-370 Ma and all have high common $\mathrm{Pb}$ so that little confidence can be placed in them as real detrital ages. A major concentration in the range 400-500 Ma with a notable peak in the distribution at $460 \mathrm{Ma}$ implies that deposition of the protolith was no older than Ordovician and probably Devonian. This is in accordance with the supposed Devonian age assigned to the Llanquihue metamorphic complex in this area by McDonough et al. (1997, and written personal communication 2001) and Hervé et al. (2016). There are minor older detrital components of 580-640 Ma, 900-1400 Ma and $c a .2650 \mathrm{Ma}$.

CM40610 is a metasandstone from the Lacui unit of the Bahia Mansa Metamorphic Complex of the Chilean Coast Range. The U-Pb analyses (Fig. 5) show a broad range of Devonian ages (370-410 Ma), the younger set of 21 yielding a possible provenance age of $378 \pm 3 \mathrm{Ma}$. There is a small resolvable sub-

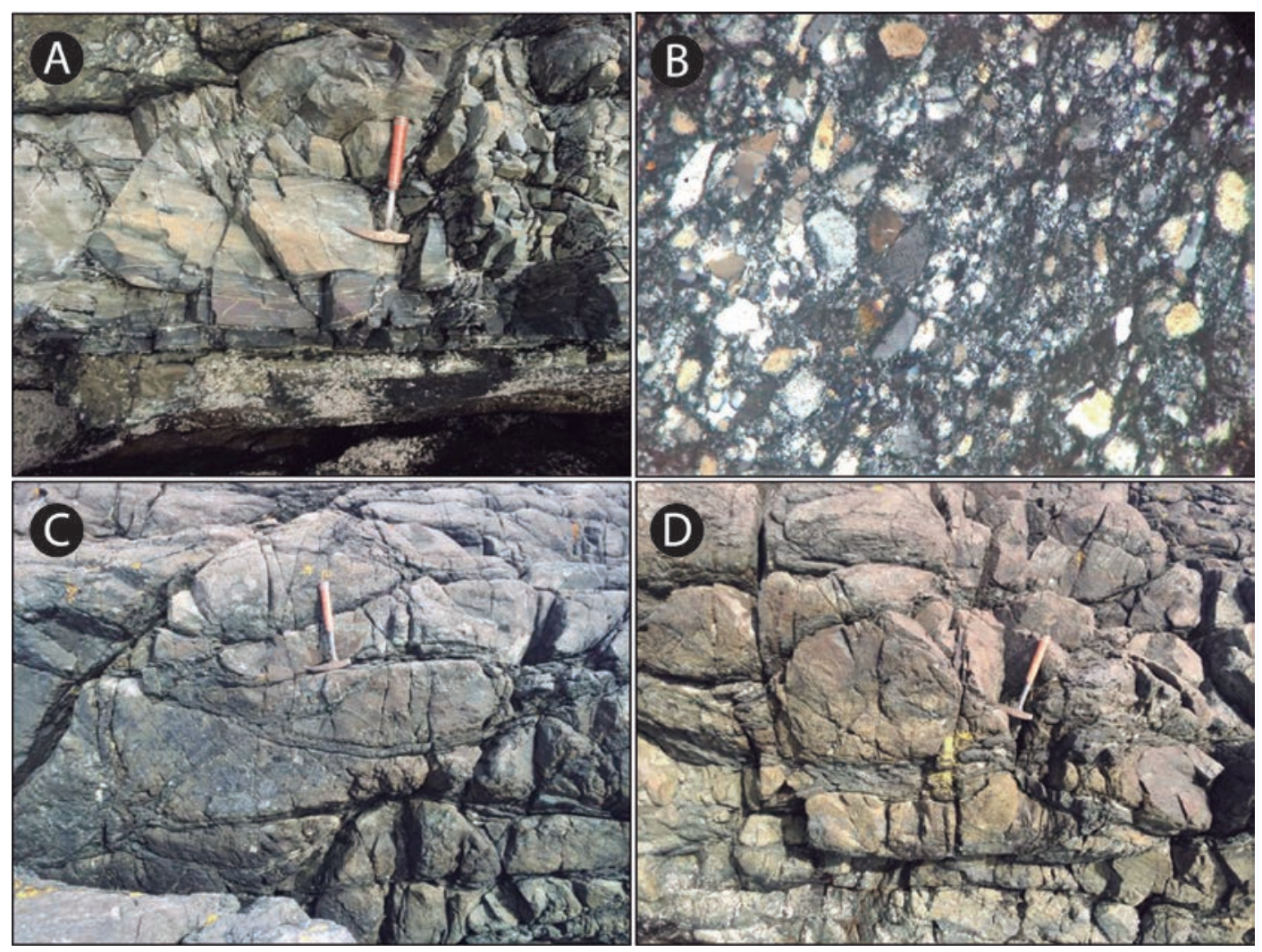

FIG. 7. A. Metasandstone layer intercalated between the pillow metabasalts at Reñihue fjord from where sample FO16109 was collected, which has Devonian detrital zircons; B. FO16109 metasandstone under the microscope, showing faintly oriented quartz and feldspar angular to subrounded grains in a recrystallized quartzose matrix. Crossed polars, frame is $c a$. $4 \mathrm{~mm}$ wide; C. Metabasalt at Reñihue fjord showing well preserved pillow structures; D. Pillowed metabasalt at Reñihue fjord interpreted as tectonically inverted. 
group at $470 \mathrm{Ma}$ and scattered older ages include three Archaean grains at 2700 Ma but very few "Grenville" ages.

\subsection{Igneous Rocks}

FO14113 is a granodiorite dyke, several metres wide with biotite-rich inclusions, which intrudes the Cuesta de Rahue schists, but has no penetrative foliation. Other white-mica bearing pegmatitic dykes are associated with the one dated here. Some of the dated zircon grains (Fig. 6) are Mesoproterozoic (1000-1200 Ma) and one is Archaean (these could easily have been assimilated from the country rock schist), but the majority (twelve) yielded a weighted mean Pennsylvanian age of $306 \pm 2 \mathrm{Ma}$, which is interpreted as the crystallization age of the granodiorite. Four younger ages probably reflect degrees of $\mathrm{Pb}-$ loss. Dyke emplacement is thus contemporaneous with that of the Coastal Batholith in south-central Chile (Fig. 1).

FO1530 is a tonalite from the northern shore of lago Nahuel Huapi. It probably intrudes the Colohuincul Formation known to crop out in this area (Cruz Martínez et al., 2012) and was considered as possibly Paleozoic. However, our results show a simple spread of Jurassic ${ }^{206} \mathrm{~Pb} /{ }^{238} \mathrm{U}$ ages from 174 to $190 \mathrm{Ma}$ (and a single $970 \mathrm{Ma}$ ), with a clear main peak at $184 \pm 2 \mathrm{Ma}$ (Fig. 6).

FO14175 is a rhyolite which forms part of the accretionary complex of the Chilean coastal basement at Zarao. U-Pb zircon data (Fig. 6) yield ${ }^{206} \mathrm{~Pb} /{ }^{238} \mathrm{U}$ ages that range from 376 to $412 \mathrm{Ma}$, beyond expected analytical error. Discounting one with excessive common $\mathrm{Pb}$, the youngest seven give a weighted mean of $382 \pm 3 \mathrm{Ma}(\mathrm{MSWD}=0.7)$ and the next thirteen give $393 \pm 3 \mathrm{Ma}(\mathrm{MSWD}=1.4)$. Intrusion must have occurred during the Eifelian (or possibly Emsian) age, in accordance with previous dating of

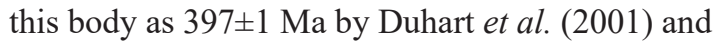
Hervé et al. (2016). The contacts with surrounding metamorphic rocks are necessarily tectonic, as the country rocks have younger detrital zircons (Hervé et al., 2016).

FO16149 is a sample of the Colán Conhue porphyritic granite, previously dated as $394 \pm 4 \mathrm{Ma}$ by Pankhurst et al. (2006). This was taken for confirmation of the Devonian age and to see if there might be an inheritance record. The U-Pb age given by 22 of the 23 analyses (excluding the lowest age of $382 \mathrm{Ma}$ ) is $390 \pm 2 \mathrm{Ma}$, with an MSWD of 1.1 (Fig. 6). This is satisfactorily well within error of the previous result, but the data reveal no useful evidence of older inheritance.

\section{Discussion}

\subsection{Pre-Devonian detrital zircon provenance analysis}

In both the present-day Andean fore-arc and the North Patagonian Massif, detrital zircon age distributions in the sampled metamorphic rocks show variable pre-Devonian provenance but are generally consistent with derivation from the contemporaneous continental margin of Gondwana.

An Archaean component is found in most samples and is volumetrically significant at Buill and Río Chico; even a few grains of Paleoarchaean (ca. 3,500 Ma) are characteristic of the outcrops at lago Gutiérrez and río Collon Curá. This component does not seem to occur in the more westerly outcrops. The sources of the Archaean detritus are uncertain, especially in view of low abundance consistent with multi-cycle reworking, but would be compatible with an ultimate source in southern Africa, the only nearby area within the Gondwana assemblage that has rocks proven to extend back in time to $3500 \mathrm{Ma}$ (Drabon et al., 2017). Similar low-abundance Archaean provenance is occasionally found in rocks of many ages in southern South America (Pankhurst et al., 2006; Hervé et al., 2013).

In the northeast of the study area (cuesta de Rahue and estero El Loco) a spread of "Grenvilleage" zircons predominate in the detrital material of the Colohuincul Formation, as previously noted by Ramos et al. (2010). The range extends to ca. $1400 \mathrm{Ma}$, a spread of Mesoproterozoic ages that is typically found in the basement of the Western Sierras Pampeanas of NW Argentina exposed by Tertiary uplift (see Rapela et al., 2016 for review); the comparison even extends to similar traces of Archaean provenance. The proto-Gondwana margin of continental South America would thus seem to be a probable source area. Deposition could conceivably have been as early as early Neoproterozoic although traces of Ordovician zircon suggest that mid-Paleozoic is more likely, as noted below. It is significant that the same spread of Mesoproterozoic zircon ages (ca. 1100, 1250 and 1350-1400 Ma) occurs in almost 
all of the other samples analysed, although generally in smaller proportions.

Late Neoproterozoic detrital zircon (500-650 Ma, and even up to $850 \mathrm{Ma}$ ) is a major detrital component on both the eastern flank of the Andes and at Buill. Although it is absent from the Brazo Tronador and Lacui samples, both still have notable "Grenville" and older peaks. Detrital zircon in this age range is quite common throughout the South American margin of Gondwana (Ireland et al., 1998; Cawood et al., 1999; Goodge et al., 2004), and potential igneous sources may be found in the orogenic belts of eastern Brazil and, to some extent, the Sierras Pampeanas.

Ordovician detrital zircon comprises a prominent age peak in many samples, e.g., those from the Cushamen Formation on the Argentine side of the Andes, the Buill meta-sandstone and the HUI-T8 borehole core. Scarce detrital zircons of possible Ordovician age were also found at cuesta de Rahue and estero El Loco. Granite magmatism of this age (Famatinian) is well known throughout the protoGondwana margin of South America, extending from the northern Andes as far as the northeastern part of the North Patagonian Massif (Pankhurst et al., 2006, 2014; Varela et al., 2009).

\subsection{Devonian zircon ages}

Even though individual apparent ages as young as Carboniferous or Permian have been obtained, in many cases identification of post- $470 \mathrm{Ma}$ events is inconclusive since these ages are usually associated with high common $\mathrm{Pb}$ contents and possible subsequent $\mathrm{Pb}$-loss. Nevertheless, Devonian ages of ca. $400 \mathrm{Ma}$ obtained in scattered outcrops of metamorphic rocks cropping out at both sides of the main Andes, have given $\mathrm{U}-\mathrm{Pb}$ zircon data consistent with them being Devonian country rocks affected by Devonian metamorphism and/or magmatism (Cruz Martínez et al., 2012; Hervé et al., 2016).

A Devonian age for deposition is fully established in the case of the Buill metasandstones by both fossil content and the age of $407 \pm 5 \mathrm{Ma}$ for the youngest detrital zircon component. Our data from all the other samples analysed are consistent with a similar sedimentary age (if a very few younger ages with high common $\mathrm{Pb}$ contents are discounted as noted above). A few kilometres south of Buill, on the southern shore of Reñihue fjord, a Middle Devonian (388 $\pm 2 \mathrm{Ma})$ detrital zircon maximum depositional age was obtained in a fine-grained metasandstone (Fig. 7A and B), which is found between a thick pile ( $\mathrm{km}$ wide) of pillowed metabasalt, parts of the stratigraphic section interpreted as tectonically inverted (Fig 7C and D). Given the oceanic nature of the metabasalts which are spatially associated to ultramafic rocks (Crignola, 1999; Hervé et al., 2017), and the proximity of these with the presentday location of the Chaitenia magmatic axis (Fig. 8), the turbidite-pillow basalt-ultramafic rocks associations cropping out at Reñihue fjord rise up as the most probable country rocks of the Devonian magmatism in the Chaitenia terrane, at these latitudes. At Lacui, in the Bahía Mansa metamorphic complex, a Devonian maximum possible sedimentation age was obtained for a metasandstone resembling those of the Llanquihue metamorphic complex (Hervé et al., 2016).

In the western edge of the North Patagonian Massif, Devonian detrital zircon $(406 \pm 3 \mathrm{Ma})$ was obtained at río Lipinza (where it is far more evident than Ordovician provenance), and in two of the Cushamen Formation samples.

Two of the igneous rocks dated here are Devonian. On the basis of our data, the Zarao rhyolite could be as young as $382 \pm 3 \mathrm{Ma}$, but our preferred age estimate is $393 \pm 3 \mathrm{Ma}$, consistent both with the result of Duhart et al. (2001) and with our confirmed age of the Colán Conhue granite. These ages imply magmatism penecontemporaneous with the EmsianEifelian deposition of the Buill slate protolith, which contains slightly older detrital zircons $(407 \pm 5 \mathrm{Ma})$. After Quezada (2015) and Vildoso (2017) the Zarao rhyolite is geochemically similar to siliceous alkaline differentiated rocks from oceanic islands or mid ocean ridges. If we consider that the Zarao rhyolite is at least $c a$. 5 My older than the oldest neighbouring metamorphic rocks (Fig. 2), then is reasonable to suggest that the Zarao rhyolite was not intruded into the accretionary prism, but was transported and tectonically emplaced in it.

On the other hand, U-Pb SHRIMP dating of zircon from other igneous intrusive rocks in the coastal metamorphic complex slightly east of Buill (Hervé et al., 2016) suggest continuation of magmatism and sedimentation in Chaitenia into Late Devonian times (Pichicolo 384 \pm 3 Ma, Chaitén $383 \pm 2 \mathrm{Ma}$, Centro del Mundo quarry $361 \pm 7 \mathrm{Ma}$ ).

Previous $\mathrm{O}$ and $\mathrm{Hf}$ isotope work (Hervé et al., 2016) has shown that Devonian detrital zircons in diverse Paleozoic metamorphic rock units in 


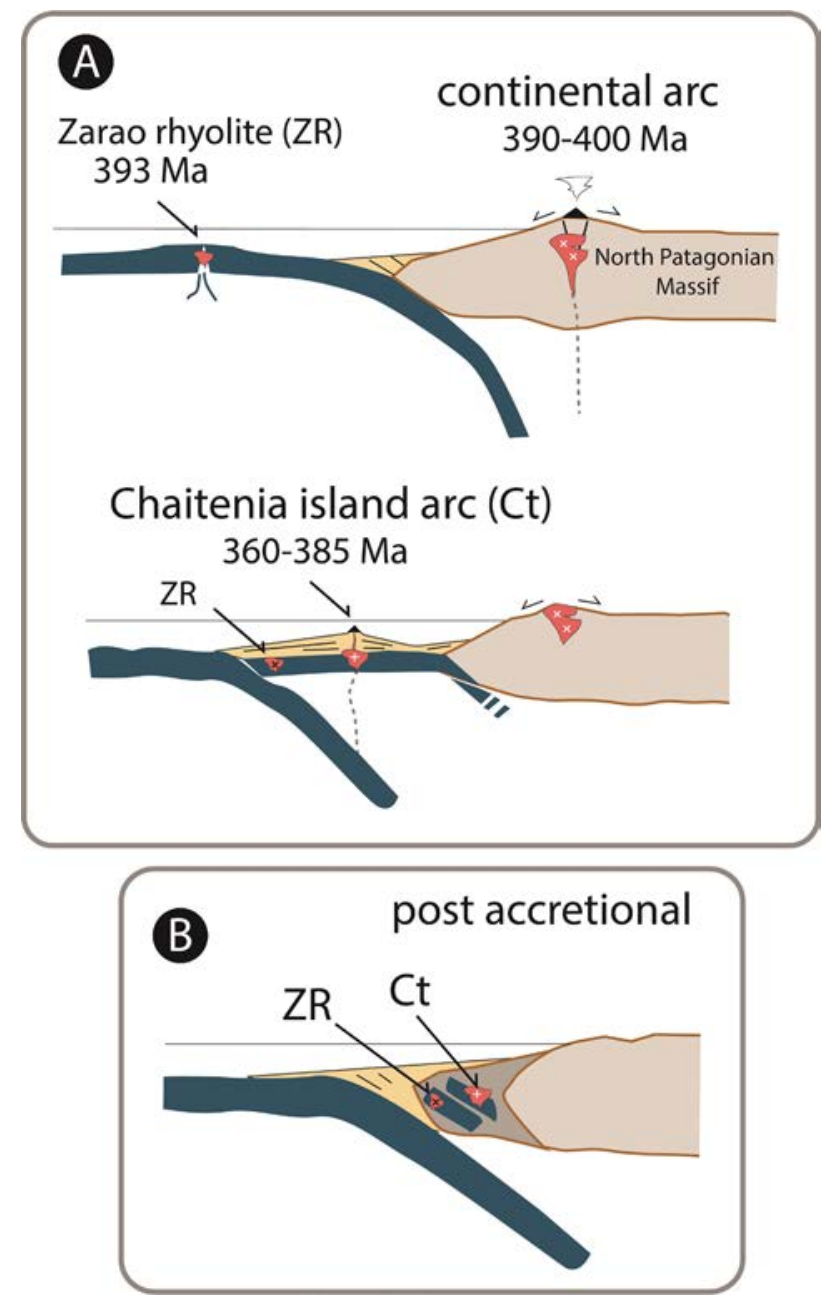

FIG. 8. A. Schematic cross sections showing the assumed relationships between the different Paleozoic tectonic units in the Gondwana margin at 41 to $42^{\circ} \mathrm{S}$ (present coordinates) at two different Devonian time slots. B. Schematic cross section showing main tectonic units at the same latitude, after assumed post Devonian accretion of Chaitenia to the Gondwana margin.

the present day coastal region at these latitudes, including probably Devonian metasedimentary rocks in the Llanquihue metamorphic complex at Los Muermos (Fig. 2), were derived from intrusive rocks of the kind that crop out in the Devonian continental arc on the eastern flank of the Andes rather than from the more primitive intrusive rocks in Chile, such as the Chaitenia arc-related plutons at continental Chiloe (Quezada et al., 2015) and the Zarao rhyolite (FO14175, Fig. 8). This interpretation is supported by the lack of a major zircon provenance differences in the east-west transect represented by this study, except for the different percentage of the
Precambrian zircon grain age populations, which are more abundant in the North Patagonian Massif (76\%) than in Chaitenia (25\%).

Devonian metamorphism is especially clear in sample FO1527 from Brazo Tronador (lago Mascardi), where ca. 390 Ma metamorphic rims are developed on (mostly) Mesoproterozoic cores (Fig. 4). The petrographic evidence of Cruz Martínez et al. (2012) indicates that this Devonian metamorphism developed in situ in the original sedimentary protolith. No such metamorphic rims, nor the Carboniferous ones in sample FO1525, have been observed in the Chilean samples, suggesting that metamorphism 
was of lower grade farther west. If collision of a southern extension of the Chilenia terrane were responsible for this metamorphism (Cruz Martínez et al., 2012), then the latter would appear to consist mostly of post-Ordovician metasediments which is not compatible with the ages assigned to Chilenia (580-530 Ma; Álvarez et al., 2011). We prefer the concept of Chaitenia as an (initially) offshore Devonian island arc as suggested in Hervé et al., (2016) as the colliding body.

A post- 470 Ma depositional age for the majority of these samples is established by the U-Pb data for detrital zircons, but in some cases a mid-Paleozoic age is confirmed by the fact that they are intruded by igneous rocks dated at $306 \pm 2 \mathrm{Ma}$ (Cuesta de Rahue), penecontemporaneous with the Pennsylvanian Coastal Batholith of Chile (Deckart et al., 2014), and of the Devonian age in the granitic body intruding the rocks of the Llanquihue metamorphic complex (McDonough et al, written communication, 2001) at the ENAP borehole Rahue-2.

Finally, a tonalite intrusion into the basement north of Lago Nahuel Huapi has been dated at $184 \pm 2 \mathrm{Ma}$, suggesting that it may represent the northern extension to the Early Jurassic Subcordilleran batholith west of the North Patagonian Massif (Rapela et al., 2005).

The metasedimentary rocks dated here can be interpreted as part of a local backstop to the Carboniferous to Triassic accretionary complex of the coastal region. The scarcity and discontinuity of Devonian or older basement at the presently exposed crustal level result from its involvement in Late Paleozoic and Andean tectonic and magmatic processes.

\section{Conclusions}

Scattered outcrops of metamorphic rocks in the Andean region and in the western part of the North Patagonian Massif have detrital zircon grains indicating that they were deposited during (or perhaps in some cases slightly before) Devonian times. Some samples show the effects of a Devonian metamorphic event, which has been previously assigned to the collision of Chilenia with Patagonia. Here we prefer to consider a collision of a separate oceanic island arc suspect terrane, Chaitenia, as suggested in Hervé et al. (2016) extending south of the Huincul lineament which is considered the southern limit of the Chilenia terrane by Ramos et al. (1986). Chaitenia plutonic rocks differ from the ones of the Devonian magmatic arc in the Patagonian Massif in the isotope geochemistry of zircon, and have different lithologies in their country rocks. However, a metasedimentary rock of Chaitenia, which is interbedded with pillow metabasalts (Fig. 7) shows no major provenance differences from those of the continental foreland, suggesting that the island arc formed in a proximal position to the Gondwana margin while magmatism was active (Fig. 8). These rocks constituted a backstop to the late Carboniferous -Triassic accretionary prism which extends further west.

\section{Acknowledgements}

Chilean Fondecyt projects 1130227 and 1180457 financed this research. Some of the sampling and analysis in the North Patagonian Massif was carried out earlier with support from CONICET (Argentina) and British Antarctic Survey. Dr. F. Fuentes (Universidad Andrés Bello) and students C. Palape, C. Marambio (Universidad de Chile) and F. Vildoso (Universidad Andrés Bello) participated in part of the field work. C. Mpodozis and V. Ramos gave useful reviews.

\section{References}

Álvarez, J.; Mpodozis, C.; Arriagada, C.; Salazar, E.; Morata, D.; Peña, M. 2009. Circones Detríticos del Complejo Metamórfico El Tránsito, Cordillera de Vallenar: ¿Evidencias acerca del basamento de Chilenia? In Congreso Geológico Chileno, No. 12: S9_001. Santiago.

Álvarez, J.; Mpodozis, C.; Arriagada, C.; Astini, R.; Morata, D.; Salazar, E.; Valencia, V.A.; Vervoort, J.D. 2011. Detrital zircons from late Paleozoic accretionary complexes in north-central Chile $\left(28^{\circ}-32^{\circ} \mathrm{S}\right)$ : Possible fingerprints of the Chilenia Terrane. Journal of South American Earth Sciences 32: 460-476. doi: 10.1016/j. jsames.2011.06.002.

Álvarez, J.; Murillo, I.; Mpodozis, C. 2013a. U-Pb ages and metamorphic evolution of the La Pampa Gneisses and the Quebrada Seca Schists: implications for the evolution of the Chilenia Terrane and Permo-Triassic tectonics of North-Central Chile. Bolletino de Geofísica Teórica et Applicata 54, Supplement 2: 35-36.

Álvarez, J.; Mpodozis, C.; Blanco-Quintero, I.F.; GarcíaCasco, A.; Morata, D.; Arriagada, C. 2013b. U/Pb geochronology and P-T-t path of the La Pampa Gneisses, implications for the evolution of the Chilenia Terrane and Permo-Triassic tectonics of North-Central Chile. Journal of South American Earth Sciences 47: 100-115. 
Cawood, P.A.; Nemchin, A.A.; Leverenz, A.; Saeed, A.; Ballance, P.F. 1999. U/Pb dating of detrital zircons: implications for the provenance record of Gondwana margin terranes. Geological Society of America, Bulletin 111: 1107-1119.

Chernicoff, C.; Zappettini, O.; Santos, J.; McNaughton, N.; Belousova, E. 2013. Combined U-Pb SHRIMP and Hf isotope study of the Late Paleozoic Yaminué Complex, Río Negro Province, Argentina: implications for the origin and evolution of the Patagonia composite terrane. Geoscience Frontiers 4: 37-56.

Cohen, K.M.; Finney, S.C.; Gibbard, P.L.; Fan, J.X. 2013. The ICS international Chronostratigraphic Chart. Episodes 36: 199-204.

Crignola, P. 1999. Geología del Fiordo Reñihue y parte occidental de la Peninsula Huequi, Chiloé Continental, X Region, Chile. Memoria de Título de Geólogo (Unpublished), Universidad de Concepción: 115 p.

Cruz Martínez, J.; Dristas, J.A.; Massonne, H.-J. 2012. Palaeozoic accretion of the microcontinent Chilenia, North Patagonian Andes: high-pressure and subsequent thermal relaxation. International Geology Review 54: 472-490.

Dalla Salda, L.H.; Cingolani, C.; Varela, R. 1991. El basamento cristalino de la región norpatagónica de los lagos Gutiérrez, Mascardi y Guilllelmo, Provincia de Río Negro. Revista de la Asociación Geológica Argentina 46: 263-276.

Deckart, K.; Hervé, F.; Fanning, C.N.; Ramírez, V.; Calderón, M.; Godoy, E. 2014. U-Pb Geochronology and Hf-O isotopes of zircons from the Pennsylvanian Coastal Batholith, South-Central Chile. Andean Geology 41 (1) 49-82. doi: 10.5027/andgeoV41n1-a03.

Drabon, N.; Lowe, D.R.; Byerly, G.R.; Harrington, J.A. 2017. Detrital zircon geochronology of sandstones of the 3.6-3.2 Ga Barberton greenstone belt: No evidence for older continental crust. Geology 45 (9): 803-806.

Duhart, P.; McDonough, M.; Muñoz, J.; Martin, M.; Villeneuve, M. 2001. El Complejo Metamórfico Bahía Mansa en la Cordillera de la Costa del centro-sur de Chile $39^{\circ} 30^{\prime \prime}-42^{\circ} 00^{\prime}$ S: geocronología K-Ar, Ar/Ar y U-Pb e implicancias en la evolución del margen sur-occidental de Gondwana. Revista Geológica de Chile 28 (2): 179-208. doi: 10.5027/andgeoV28n2-a03.

Fortey, R.; Pankhurst, R.J.; Hervé, F. 1992. Devonian trilobites at Buill, Southern Chile. Revista Geológica de Chile 19 (2): 133-144. doi: 10.5027/andgeoV19n2-a01.

García-Sansegundo, J.; Farías, P.; Gallastegui, G.; Giacosa, R.E.; Heredia, N. 2009. Structure and metamorphism of the Gondwana basement in the Bariloche region
(North Patagonian Argentine Andes). International Journal of Earth Sciences 98: 1599-1608.

Godoy, E.; Hervé, F.; Fanning, C.M. 2008. Edades $\mathrm{U}-\mathrm{Pb}$ SHRIMP en $38^{\circ} \mathrm{S}$ de granitoides del Macizo Norpatagónico: implicancias geotectónicas. In Congreso Geológico Argentino, No. 17, Actas 3: 1288-1289. San Salvador de Jujuy.

Goodge, J.W.; Williams, I.S.; Myrow, P. 2004. Provenance of Neoproterozoic and lower Paleozoic siliciclastic rocks of the central Ross orogen, Antarctica: Detrital record of rift-, passive-, and active-margin sedimentation. Geological Society of America, Bulletin 116: 1253-1279.

Hervé, F. 1988. Late Paleozoic subduction and accretion in Southern Chile. Episodes 11: 183-188.

Hervé, F.; Fanning, C.M.; Pankhurst, R.J. 2003. Detrital Zircon Age Patterns and Provenance of the metamorphic complexes of Southern Chile. Journal of South American Earth Sciences 16: 107-123.

Hervé, F.; Faúndez, V.; Calderón, M.; Massonne, H.-J.; Willner, A.P. 2007. Metamorphic and plutonic basement complexes. In The Geology of Chile (Moreno, T.; Gibbons, W.; editors), The Geological Society: 5-19. London.

Hervé, F.; Calderón, M.; Fanning, C.M.; Pankhurst, R.J.; Godoy, E. 2013. Provenance variations in the Late Paleozoic accretionary complex of central Chile as indicated by detrital zircons. Gondwana Research 23: 112-113.

Hervé, F.; Fanning, M.; Calderón, M.; Mpodozis, C.; 2014. Early Permian to Late Triassic batholiths of the Chilean Frontal Cordillera $\left(28^{\circ}-31^{\circ} \mathrm{S}\right)$ : SHRIMP $\mathrm{U}-\mathrm{Pb}$ zircon ages and $\mathrm{Lu}-\mathrm{Hf}$ and $\mathrm{O}$ isotope systematic. Lithos 184-187: 436-446.

Hervé, F.; Calderón, M.; Fanning, C.M.; Pankhurst, R.J.; Fuentes, F.; Rapela, C.W.; Correa, J.; Quezada, P.; Marambio, C. 2016. Devonian magmatism in the accretionary complex of southern Chile. Journal of the Geological Society 173: 587-602. doi:10.1144/ jgs2015-163. London.

Hervé, F.; Fuentes, F.; Calderón, M.; Fanning, C.M.; Quezada, P.; Pankhurst, R.J.; Rapela, C.W. 2017. Ultramafic rocks in the North Patagonian Andes: is their emplacement associated with the Neogene tectonics of the Liquiñe-Ofqui Fault Zone? Andean Geology 44 (1): 1-16. doi: 10527/andeangeov44n1-a01.

Ireland, T.R.; Flötmann, T.; Fanning, C.M.; Gibson, G.M.; Preiss, W.V. 1998. Development of the early Paleozoic Pacific margin of Gondwana from detrital-zircon ages across the Delamerian orogen. Geology 26: 243-246. 
Levi, B.; Aguilar, A.; Fuenzalida, R. 1966. Reconocimiento geológico en las provincias de Llanquihue y Chiloé. Instituto de Investigaciones Geológicas, Boletin 19: 45 p. Santiago.

Ludwig, K.R. 2003. Isoplot 3.0 A Geochronological Toolkit for Microsoft Excel. Berkeley Geochronology Center, Special Publication 4: 70 p.

McDonough, M.; Ugalde, H.; Duhart, P.; Crignola, P. 1997. Nuevos antecedentes estructurales de la Cordillera de la Costa y el adyacente Valle Central en la parte norte de la X Región, Chile: su relación con el patrón magnético. In Congreso Geológico Chileno, No. 8, Actas 1: 169-172. Antofagasta.

Ostera, H.A.; Linares, E.; Haller, M.J.; Cagnoni, M.C.; López de Luchi, M. 2001. A widespread metamorphic Devonian episode in Northern Patagonia, Argentina. In South American Symposium on Isotope Geology, No. 3, Actas CD: 52, Resúmenes: p. 161. Santiago.

Pankhurst, R.J.; Rapela, C.W.; Fanning, C.M.; Márquez, M. 2006. Gondwanide continental collision and the origin of Patagonia. Earth-Science Reviews 76: 235-257.

Pankhurst, R.J.; Rapela, C.W.; López de Luchi, M.G.; Rapalini, A.E.; Fanning, C.M.; Galindo, C. 2014. The Gondwana connections of Patagonia. Journal of the Geological Society 171: 313-328.

Quezada, P. 2015. Geología del basamento de la Región de Los Lagos, Chile: evidencias de magmatismo calco alcalino y aportes sedimentarios devónicos. Graduation thesis (Unpublished), Universidad de Chile, Departamento de Geología: 105 p. Santiago.

Quezada, P.; Hervé, F.; Calderón, M.; Fuentes, F.; Fanning, C.M.; Pankhurst, R.J.; Rapela, C.W.; Correa, J. 2015. Contrasting magmatic sources of Devonian calc-alkaline magmatism emplaced in the western slope of the Andes, Chile, and North Patagonian Massif, Argentina (40-43ㅇ Sat.). In Congreso Geológico Chileno, No. 14 (Charrier, R.; Hervé, F.; Maksaev, V.; Mpodozis, C.; Oyarzún, J.; editors): ST3_066. La Serena.

Ramos, V.A.; Jordan, T.; Allmendinger, R.; Kay, S.M.; Cortés, J.M.; Palma, M.A. 1984. Chilenia: un terreno alóctono en la evolución paleozoica de los Andes Centrales. In Congreso Geológico Argentino, No 9, Actas 2: 84-106. San Carlos de Bariloche.

Ramos, V.A.; Jordan, T.E.; Allmendinger, R.W.; Mpodozis, C.; Kay, S.M.; Cortés, J.; Palma, M. 1986. Paleozoic terranes of the Central Argentine Chilean Andes. Tectonics 5: 855-880.

Ramos, V.; García-Morabito, E.; Hervé, F.; Fanning, C.M. 2010. Grenville age sources in Cuesta de Rahue, Northern Patagonia: constrains from U-Pb SHRIMP ages from detrital zircons. Geosur 2010, Bolletino di Geofísica teórica ed applicata 51 (supplement): 42-45. Mar del Plata.

Rapela, C.W.; Pankhurst, R.J.; Fanning, C.M.; Hervé, F. 2005. Pacific subduction coeval with the Karoo mantle plume: the Early Jurassic Subcordilleran belt of northwestern Patagonia. In Terrane Processes at the Margins of Gondwana (Vaughan, A.P.M.; Leat, P.T.; Pankhurst, R.J.; editors), Geological Society, Special Publication 246: 217-240.

Rapela, C.W.; Verdecchia, S.O.; Casquet, C.; Pankhurst, R.J.; Baldo, E.G.; Galindo, C.; Murra, J.A.; Dahlquist, J.A.; Fanning, C.M. 2016. Identifying Laurentian and SW Gondwana sources in the Neoproterozoic to Early Paleozoic metasedimentary rocks of the Sierras Pampeanas: paleogeographic and tectonic implications. Gondwana Research 32: 198-212: doi: 10.1016/j.gr.2015.02.010.

SERNAGEOMIN, 2003. Mapa geológico de Chile, versión digital. Servicio Nacional de Geología y Minería, Publicación Geológica Digital, No. 4 CDRoom, versión 1.0, base geológica escala 1:1.000.000.

Varela, R.; Cingolani, C.A.; Passarelli, C.R.; Basei, M.A.S. 2005. El basamento cristalino de los Andes Norpatagónicos en Argentina: geocronología e interpretación tectónica. Revista Geológica de Chile 32 (2): 167-187. doi: 10.5027/andgeoV32n2-a01.

Varela, R.; Sato, K.; González, P.D.; Sato, A.M.; Basei, M.A.S. 2009. Geología y geocronología Rb-Sr de granitoides de Sierra Grande, Provincia de Río Negro. Revista de la Asociación Geológica Argentina 64: 275-284.

Vildoso, M.F. 2017. Petrología del basamento metavolcánico Devónico de la Cordillera del Zarao, Los Muermos, Región de los Lagos, Chile. Graduation thesis (Unpublished), Universidad de Andrés Bello, Carrera de Geología: 67 p. Santiago.

Williams, I.S. 1998. U/Th/Pb geochronology by ion microprobe. In Applications of microanalytical techniques to understanding mineralizing processes. (McKibben, M.A.; Shanks, W.C.; Ridley, W.I.; editors) Reviews in Economic Geology 7: 1-35. 